FESIEE

Fundación Emilio Soldevilla de la Ecostigacion y Desarrotio

\section{Management Letters / Cuadernos de Gestión}

journal homepage: http://www.ehu.eus/cuadernosdegestion/revista/es/

ISSN: 1131-6837 / e-ISSN: 1988-2157

\title{
Bibliometric and systemic analysis of the relationship between management and carbon
}

\section{Análisis bibliométrico y sistémico de la relación entre la gestión y el carbono}

\author{
Yenny Naranjo Tuesta ${ }^{*}$, Cristina Crespo Soler ${ }^{\mathrm{a}}$, Vicente Ripoll Feliu ${ }^{\mathrm{b}}$ \\ a Member of AICOGestión. PDI Titular D University. Vice Dean of Participation, Volunteering and Equality. Accounting Department - Faculty of Economics University of \\ Valencia. - cristina.crespo@uv.es - https://orcid.org/0000-0003-0704-4578 \\ ${ }^{b}$ President of AICOGestión. PDI Titular D University. Accounting Department - Faculty of Economics University of Valencia. - vicente.Ripoll@uv.es - https://orcid. \\ org/0000-0003-2436-1559
}

* Corresponding author: Member of AICOGestión. PhD in Accounting and Corporate Finance at the University of Valencia. - jnaranjot@unal.edu.co - https://orcid. org/0000-0001-9301-373X

\section{A R T I C L E I N F O}

Received 11 February 2021,

Accepted 31 October 2021

Available online 10 February 2022

DOI: $10.5295 / \mathrm{cdg} .211442 \mathrm{yn}$

JEL: F64, M41, Q56

\begin{abstract}
A B S T R A C T
This paper aims to present a bibliometric and systemic analysis of the Bibliographic Portfolio (BP) jointly examining the literature related to topics like "Greenhouse gas," mainly carbon, and "Management," as published in databases data such as Web of Science and Scopus in the field of economic and social sciences. The Knowledge and Constructivist Development Process methodology — Proknow-C - was used to establish the final portfolio and through the VosViewer program were mapped the various groups or relationships between the studied literature. The paper presents the theoretical and methodological aspects focusing on the areas and countries of study and highlighting the most relevant authors to have researched this particular topic. We use this constructivist model to describe the measurement variables and synthesize the concepts most used in these studies in order to propose new focal points and thematic approaches that could be developed further in the future.
\end{abstract}

Keywords: Carbon Management, Greenhouse Gases, Climate Change, Management Accounting, Management System, Proknow-C.

\section{R E S U M E N}

Este trabajo tiene como objetivo presentar un análisis bibliométrico y sistémico del Portafolio Bibliográfico (PB) examinando conjuntamente la literatura relacionada con temas como "Gas de efecto invernadero", principalmente el carbono, y "Gestión", según lo publicado en bases de datos como Web of Science y Scopus, en el campo de las ciencias económicas y sociales. Se empleó la metodología del Proceso de Desarrollo del Conocimiento y Constructivismo-Proknow-C- para establecer el portafolio final y a través del programa VosViewer se mapearon los diversos grupos o relaciones entre la literatura estudiada. El trabajo presenta los aspectos teóricos y metodológicos centrándose en las áreas, países de estudio y el reconocimiento de los autores más relevantes que han investigado este tema en particular. A partir de este modelo constructivista, se describen las variables de medición y se sintetizan los conceptos más utilizados en estos estudios, con el fin de proponer nuevos enfoques temáticos que puedan desarrollarse en el futuro.

Palabras clave: Gestión del Carbono, Gases de Efecto Invernadero, Cambio Climático, Contabilidad de Gestión, Sistemas de Gestión, Proknow-C. 


\section{INTRODUCTION}

The concern about emerging climate change in the last decade is of interest to different governments, policymaking, and international organizations, from the economic, financial, and social standpoints. Not being alien to academics and researchers, a workable field opens up between the economic, accounting, and administrative sciences. Research such as Schaltegger et al. (2015) on climate change and carbon studies from a corporate perspective serves as a theoretical and conceptual basis for future research.

The Kyoto Protocol is used as a reference to establish actions that promote emissions measurement, reporting, and monitoring of activities. Regarding measurement, there are systems such as the Greenhouse Gases Protocol (GHG) (WRI \& WBCSD, 2015), which sets forth an emissions inventory, carbon accounting, and the implementation of emissions management and control systems. Similarly, the Carbon Disclosure Project (CDP), routed by information disclosure, provides knowledge on the behavior of emissions based on accounting data, both from countries and companies. Monitoring and information reporting mechanisms could come about through the global reporting initiative (GRI), driving companies to establish dissemination, communication, and feedback strategies with their stakeholders on environmental issues.

This information, particularly carbon-related information, has begun to be integrated into accounting and management studies in recent years. Although its scientific development in economic, financial, and accounting levels is relatively new, different works have materialized new approaches and research lines.(Ascui, 2014; Busch and Lewandowski, 2018; Csutora and Harangozo, 2017; Lovell et al., 2013; Stechemesser and Guenther, 2012).

In the face of such new research opportunities, this paper's main objective is to illustrate and perform a bibliographic and systemic analysis of the literature related simultaneously to carbon and management aspects to contribute to accounting sciences. By providing such an illustration, the purpose is to shed light on the main factors that authors and professionals should consider when dealing with the topics of Carbon, Management, and Accounting, altogether. To that end, we used the Proknow-C methodology and the Vosvierwer program in order to account for this existing relationship and identify the gaps that, from the literature, can be addressed as future research.

Based on previous work (Ascui, 2014; Busch and Lewandowski, 2018; Harangozó, Széchy and Zilahy, 2015; Kumarasiri and Jubb, 2016; Schaltegger et al., 2015), we selected key words and defined concepts to determine the bibliographic portfolio of this study. In regard to environmental issues, Management reviews address aspects such as mitigation strategies, business practices, management control and the information they report and provide on the management of environmental issues (Schaltegger et al., 2015). In particular, this paper presents the texts whose abstracts or keywords included the words "management accounting", "management system" or "management performance". Regarding papers on Carbon, we mainly focus on those related to climate change and with words such as "Climate change", "Greenhouse gas", "Carbon footprint" or "Emission".

Proknow-C is a constructivist methodology that, through a series of stages, underlies the consolidation of literature or bibliographic portfolio (BP) that is the source of both bibliometric and systemic analyses in order to determine research gaps (Ensslin, Ensslin and Dutra, 2014). VosViewer is a software that allows users to create maps based on network data, visualize and explore maps such as co-occurrence of keywords or bibliographic co-citation, co-authoring, among other relationships found in literature (van Eck and Waltman, 2010, 2017; Garrigos-Simon, NarangajavanaKaosiri and Narangajavana, 2019; Herrera-Franco et al., 2021).

Based on literature published in the main databases (Web of Science-WOS and Scopus), and as mentioned above, this paper aims to provide academics and organizations with information on the relationship between management and carbon, stressing the importance of financial performance, as the studies conducted reflected an interest on research in this field. To summarize, the research question that guided this work is: What are the research trends in the relationship between carbon management - carbon management accounting and profitability? In particular, we expect to identify the variables that can contribute to more empirical studies on this topic and thus contribute to the organizational environment.

This paper consists of the following sections following this introduction: first, it will describe the methodology used for the research. Next, the results of the bibliometric and systemic analysis are presented. Finally, there will be conclusions highlighting future research opportunities.

\section{METHODOLOGY}

This section describes how Proknow-C, the methodological structure used for developing this research stage, is configured. This is the methodology underlying the consolidation of the final portfolio and procedures performed throughout the (systemic) analysis of content and up until the structuring of questions and objectives for future research. There will also be an overview of the VosViewer program used in the bibliometric analysis.

By the strengthening of systemic analysis, different works have used this methodological tool to show not only the literature review but also the new opportunities in the field of research and particular topics (Caiado et al., 2017; Dutra et al., 2015; Ensslin et al., 2014; Garrigos-Simon, 2019; Mendes et al., 2017; Narangajavana-Kaosiri and Narangajavana, 2019; Viegas et al., 2016).

As shown in Figure 1, Proknow-C consists of four general stages: 1. Selecting the paper's portfolio on the topic. 2. Bibliometric analysis of the portfolio. 3. Systemic analysis, and 4. Identifying research questions and objectives. The first stage is to search the databases for the established criteria and limit papers until consolidating the bibliographic portfolio. The second stage is the VosViewer-supported ${ }^{1}$ bibliometric analysis to identify the researchers with a trajectory in this area of knowledge, relevant publications, or journals on these topics, the most recognized articles, keywords, and impact factors based on Journal Citation Reports -JCR- and SCImago Journal -SJR. The third portion will describe the systemic analysis synthesizing the BP documents' theoretical approach, models, and variables. Finally, the previously established "where and how" justify the choice of topic and the construction of research questions and objectives.

VosViewer software (1.6.9 version, University of Leiden, Leide Netherlands) for graphically mapping data. 


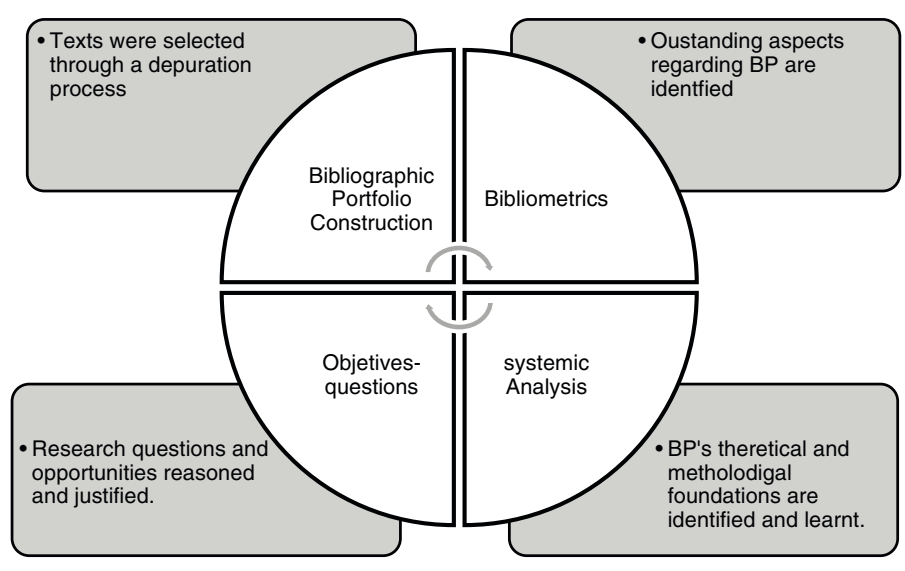

Figure 1

Stages of the Constructivist Development Process - Proknow-C

Source: Author's own elaboration based on Ensslin et al. (2014)
Table 1

Search terms

\begin{tabular}{|c|c|c|c|c|}
\hline $\begin{array}{l}\text { Carbon } \\
\text { management } \\
\text { accounting }\end{array}$ & \begin{tabular}{|l|} 
Climate \\
change \\
management \\
accounting
\end{tabular} & $\begin{array}{l}\text { Greenhouse } \\
\text { gas } \\
\text { management } \\
\text { accounting }\end{array}$ & $\begin{array}{l}\text { "Carbon } \\
\text { footprint" } \\
\text { management } \\
\text { accounting }\end{array}$ & $\begin{array}{l}\text { "Emission" } \\
\text { management } \\
\text { accounting }\end{array}$ \\
\hline $\begin{array}{l}\text { Carbon } \\
\text { management } \\
\text { system }\end{array}$ & \begin{tabular}{|l|} 
Climate \\
change \\
management \\
system
\end{tabular} & $\begin{array}{l}\text { Greenhouse } \\
\text { gas } \\
\text { management } \\
\text { system }\end{array}$ & $\begin{array}{l}\text { "Carbon } \\
\text { footprint" } \\
\text { management } \\
\text { system }\end{array}$ & $\begin{array}{l}\text { "Emission" } \\
\text { management } \\
\text { system }\end{array}$ \\
\hline $\begin{array}{l}\text { Carbon } \\
\text { management } \\
\text { performance }\end{array}$ & \begin{tabular}{|l|} 
Climate \\
change \\
management \\
performance
\end{tabular} & $\begin{array}{l}\text { Greenhouse } \\
\text { gas } \\
\text { management } \\
\text { performance }\end{array}$ & $\begin{array}{l}\text { "Carbon } \\
\text { footprint" } \\
\text { management } \\
\text { performance }\end{array}$ & $\begin{array}{l}\text { "Emission" } \\
\text { management } \\
\text { performance }\end{array}$ \\
\hline
\end{tabular}

Source: Authors' own elaboration.

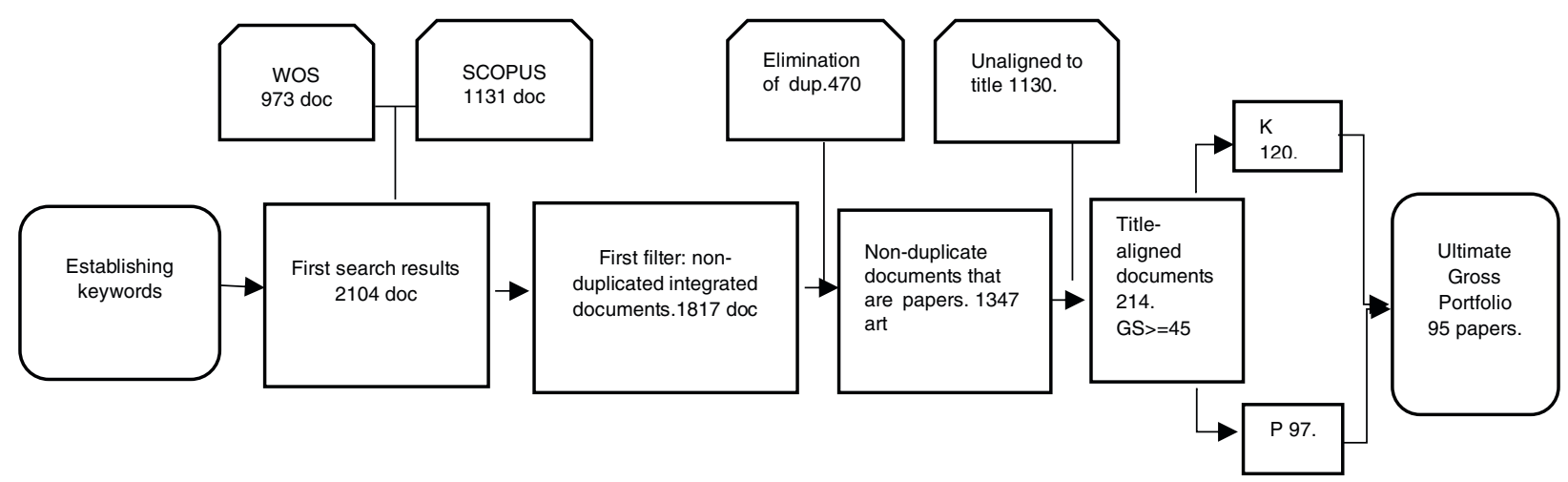

Figure 2

Filtering - Construction of portfolio

We reviewed the work by Ascui (2014), Busch \& Lewandowski (2018), Harangozó et al. (2015), Zvezdov \& Schaltegger (2016), the search words for the databases to be used were determined, establishing two categories: an environmental one focused on words such as "carbon," "climate change," "greenhouse gas," "carbon footprint" and "emission," and a management-related one containing words like "management accounting," "management system" and "management performance" (see Table 1). These are the categories underlying the search strategies that enabled the joint addressing of both topics. ${ }^{2}$

As shown in Figure 2, upon setting the keywords for selecting papers, those published as of April 20, 2020, were searched for in the Web of Science (WOS) and Scopus databases. With the list of documents resulting from the search based on the established criteria (raw documents), filtration,

${ }^{2}$ When filtering and consolidating the search strategy, other concepts such as sustainability, ecological, corporate environmental, among others, were found; however, when the word cloud was made with these documents, these were not significant, and the words included in the sample were the most representative. Therefore, the research team decided to focus on only these two areas together to create word portfolio purging, and representativeness tests were carried out to obtain the Bibliographic Portfolio (BP). Their non-duplicity was analyzed by applying an initial filter based on the title and the abstract of their central idea concerning the raw documents. Subsequently, scientific recognition is verified depending on the number of citations in Google Academic. Those exceeding the raw documents' total citations average will be regarded as "scientifically renowned," while those below the average will be classified as "potentially renowned". ${ }^{3}$

After the purging and elimination processes, and the representativeness test, we defined the documents that aligned with the strategy by title, abstract, and full text with the subject under study, which resulted in the 95 papers that make up the Bibliographic Portfolio (BP) and are the primary support of the bibliometric analysis (See Figure 2). The systemic analysis referred only to the most relevant papers in this portfolio (based on the number of citations from Google Academic).

${ }^{3}$ For our research purposes, documents with over 30 citations were regarded as impact documents, while those not above the average were held as "potentially renowned." The steps of the Proknow-C methodology were followed. 


\section{RESULTS}

This section presents the bibliometric analysis that focused on presenting the most used keywords, the journals' impact factor and co-citation, and the full BP's countries and publications per year. Subsequently, the systemic analysis will be described, delving into the most studied theories and variables and future research opportunities based on the portfolio's 30 most relevant documents.

\subsection{Results of the bibliometric analysis}

The bibliometric work carried out on the final bibliographic portfolio (95 papers) accounts for the scientific journals that disseminate this kind of research, the authors' relationship concerning co-authorship and affiliation of the projects, and the working countries on these issues, and the trend in published articles.

Figure 3 shows the co-occurrence network of author keywords in the publications that make up the BP, that is, the most common and recurring keywords in the analyzed texts.
Considering a threshold of words with at least five outputs, the result is the 40 most common keywords out of 530 used in total. The text shows that the greater the weight of the word, the greater the label; the circle and lines between the papers represent links between them; the shorter the distance between the nodes, the stronger the keywords' relationship.

This study focused on the author's keywords below the abstract, as shown in Figure 3. This technique counts the number of papers wherein two keywords appear together. The results show that the most commonly used words in this literature focus on climate change, sustainability, management, performance, carbon emissions, and companies. Also, the least used words are environmental disclosures, governance, ISO14001, control systems, and incentives. The concepts in yellow are related to management, while those in red are more related to environmental issues and those in green are related to the business, its performance and information disclosure aspects. The identification of these terms allows researchers to search for documents and to better define their information gathering and literature review strategy.

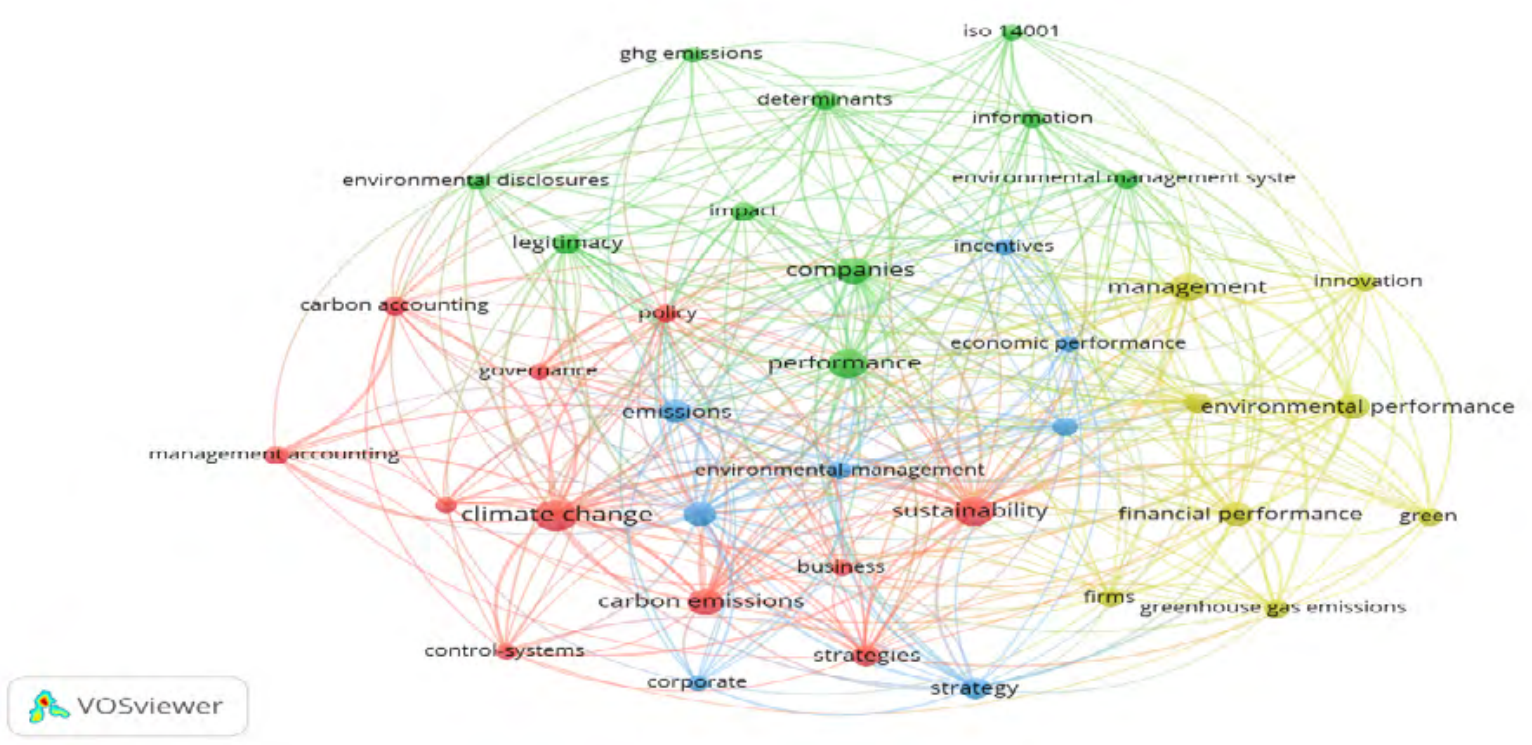

Figure 3

Keywords

Source: Authors' own elaboration.

To complement the analysis, the journals' co-citation network shown in Figure 4 was studied. We present those journals referenced in the papers that make up the BP, which resulted in the grouping of the texts by the strength of their relationship (in this case, the journals cited). This analysis's nodes account for the activity and number of published documents, while the distance between documents concerns the frequency of citation. Citation links or bibliographic links are added from the level of individual documents to the aggregate level, resulting in the existence of three central nodes plus a small one. The first node is headed by the Accounting, Organization, and Society Journal. The Journal of Cleaner Production heads the second node in purple. The third node is grouped in green with the Business Strategy and the Environment journal. Lastly, there is a small node in yellow centered around the Management Accounting Research Journal. Therefore, it can be said that these Journals are a key reference in this type of research and that researchers should consult them, as they integrate the great majority and the most representative publications on the subject. 


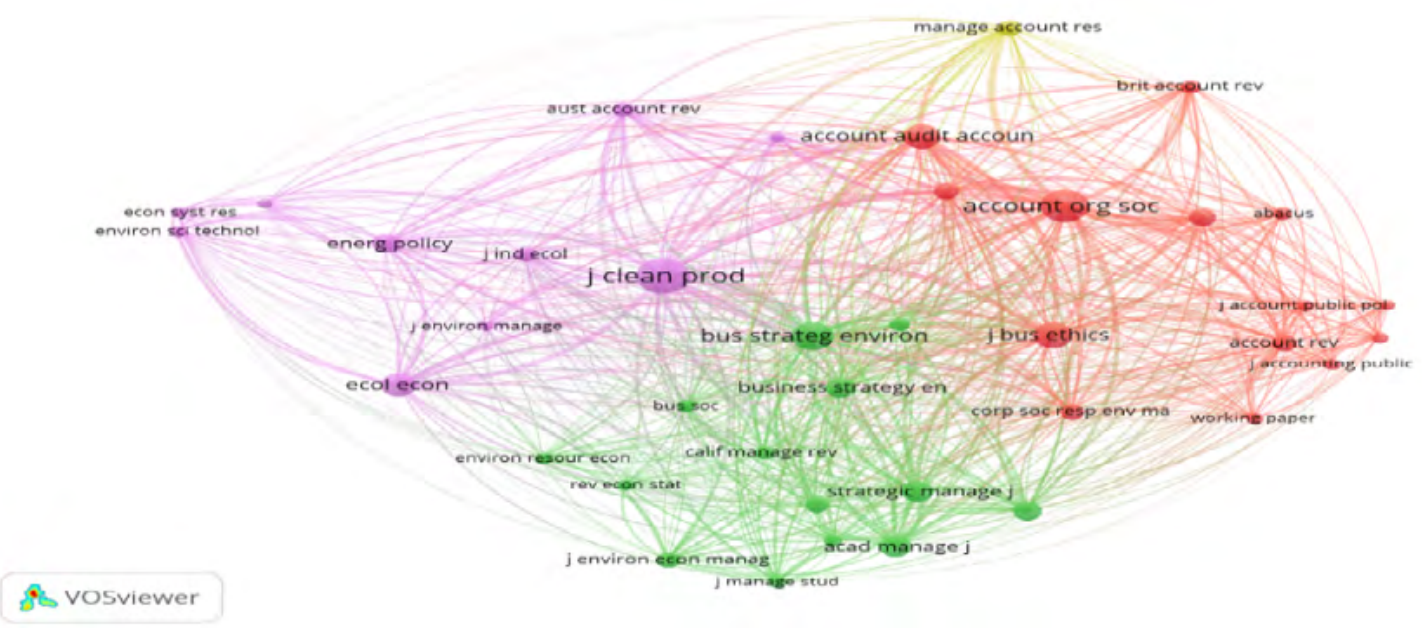

Figure 4

Journal co-citation network

Source: Authors' own elaboration.

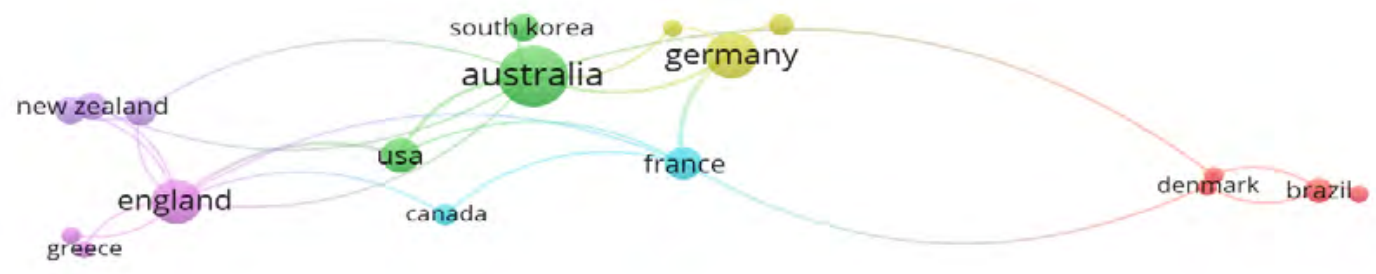

Figure 5

Countries' co-authorship network

Source: Authors' own elaboration.

Our bibliometric analysis also emphasizes co-authorship analysis to focus on the research's structure of collaboration, between countries essentially, to identify collaborative behaviors among research teams. Figure 5 shows the relationship between countries, highlighting Australia as the most collaborative country, followed by England and Germany. Out of 29 countries, 11 are shown as the authors' most representative. The distance between nodes and thickness thereof reveals the degree of collaboration between countries, while their influence is shown on the different nodes (representative colors).

The factor associated with each journal is an important measure to assess its impact on the medium and consider how it influences the scientific community. Figure 6 accounts for the studied journals' impact factor, which shows that the JCR measure is perceived and regarded highly, scoring an average of about three points. As for the SJR measure, only one publication was valued as positively impacting; on a general level, there is no clear trend regarding its quality indicator. Researchers should consider this when selecting the journal and its impact on the community. Although overall it can be said that, by being included in these rankings, the research conducted on the subject is of interest and will have an impact.

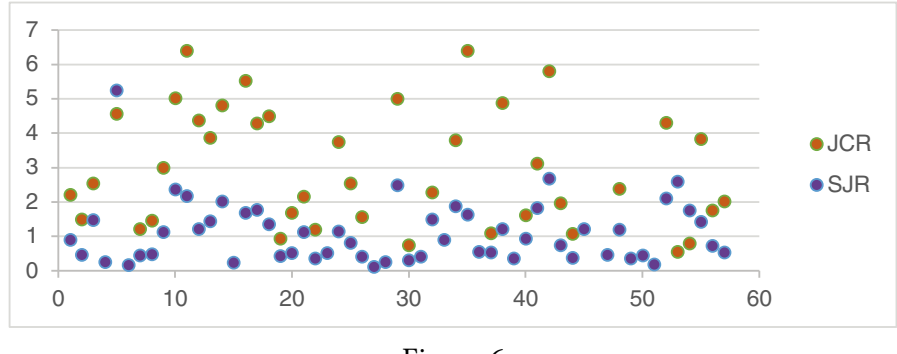

Figure 6

Impact Factor

Source: Authors' own elaboration.

Table 2 shows the most representative works by citation level along with their characteristics. This list contains BP's most influential documents, which represent $53 \%$ of citations and, in turn, attest to their relevance and consistency with the selected topic. Within this group and on an individual level, there are over 170 citations, thus proving the works relevant. The most cited is Wagner's 2005 paper, with 386 citations in Google Scholar (GS), being one of the oldest documents to address this topic. 
Table 2

Top 12 papers by title (citations from Google Scholar)

\begin{tabular}{|c|c|c|c|c|c|}
\hline No & Authors, Primary & Title Primary & Journal & Year & GS \\
\hline 1 & Wagner, $\mathrm{M}$ & $\begin{array}{l}\text { How to reconcile environmental and economic } \\
\text { performance to improve corporate sustainability: corporate } \\
\text { environmental strategies in the European paper industry }\end{array}$ & $\begin{array}{l}\text { Journal Of } \\
\text { Environmental } \\
\text { Management }\end{array}$ & 2005 & 386 \\
\hline 2 & $\begin{array}{l}\text { Matsumura, E. M., } \\
\text { Prakash, R., \& } \\
\text { Vera-Muñoz, S. C. }\end{array}$ & $\begin{array}{l}\text { Firm-Value Effects of Carbon Emissions and Carbon } \\
\text { Disclosures }\end{array}$ & Accounting Review & 2014 & 377 \\
\hline 3 & Wagner, $\mathrm{M}$ & $\begin{array}{l}\text { Empirical influence of environmental management on } \\
\text { innovation: Evidence from Europe }\end{array}$ & $\begin{array}{l}\text { Ecological } \\
\text { Economics }\end{array}$ & 2008 & 309 \\
\hline 4 & Wagner, M & $\begin{array}{l}\text { The role of corporate sustainability performance } \\
\text { for economic performance: A firm-level analysis of } \\
\text { moderation effects }\end{array}$ & $\begin{array}{l}\text { Ecological } \\
\text { Economics }\end{array}$ & 2010 & 283 \\
\hline 5 & $\begin{array}{l}\text { Prado-Lorenzo, José Manuel. } \\
\text { Rodríguez-Domínguez, Luis } \\
\text { Gallego-Álvarez, Isabel } \\
\text { García-Sánchez, Isabel María }\end{array}$ & $\begin{array}{l}\text { Factors influencing the disclosure of greenhouse gas } \\
\text { emissions in companies world-wide }\end{array}$ & $\begin{array}{l}\text { Management } \\
\text { Decision }\end{array}$ & 2009 & 257 \\
\hline 6 & $\begin{array}{l}\text { Busch, Timo } \\
\text { Hoffmann, Volker H. }\end{array}$ & $\begin{array}{l}\text { How hot is your bottom line? linking carbon and financial } \\
\text { performance }\end{array}$ & Business \& Society & 2011 & 252 \\
\hline 7 & $\begin{array}{l}\text { Iwata, } \mathrm{H} \text {; } \\
\text { Okada, K }\end{array}$ & $\begin{array}{l}\text { How does environmental performance affect financial } \\
\text { performance? Evidence from Japanese manufacturing } \\
\text { firms }\end{array}$ & $\begin{array}{l}\text { Ecological } \\
\text { Economics }\end{array}$ & 2011 & 239 \\
\hline 8 & $\begin{array}{l}\text { Rankin, M. } \\
\text { Windsor, C. } \\
\text { Wahyuni, D. }\end{array}$ & $\begin{array}{l}\text { An investigation of voluntary corporate greenhouse gas } \\
\text { emissions reporting in a market governance system: } \\
\text { Australian evidence }\end{array}$ & $\begin{array}{l}\text { Accounting, Auditing } \\
\text { \& Accountability } \\
\text { Journal }\end{array}$ & 2011 & 231 \\
\hline 9 & $\begin{array}{l}\text { Schaltegger, S. } \\
\text { Csutora, M. }\end{array}$ & $\begin{array}{l}\text { Carbon accounting for sustainability and management. } \\
\text { Status quo and challenges }\end{array}$ & $\begin{array}{l}\text { Journal Of Cleaner } \\
\text { Production }\end{array}$ & 2012 & 231 \\
\hline 10 & $\begin{array}{l}\text { Stechemesser, Kristin; } \\
\text { Guenther, Edeltraud }\end{array}$ & Carbon accounting: a systematic literature review & $\begin{array}{l}\text { Journal Of Cleaner } \\
\text { Production }\end{array}$ & 2012 & 216 \\
\hline 11 & $\begin{array}{l}\text { Burritt, Roger L.; } \\
\text { Schaltegger, Stefan; } \\
\text { Zvezdov, Dimitar }\end{array}$ & $\begin{array}{l}\text { Carbon Management Accounting: Explaining Practice in } \\
\text { Leading German Companies }\end{array}$ & $\begin{array}{l}\text { Australian } \\
\text { Accounting Review }\end{array}$ & 2011 & 183 \\
\hline 12 & Lee, KH; Min, B & $\begin{array}{l}\text { Green R\&D for eco-innovation and its impact on carbon } \\
\text { emissions and firm performance }\end{array}$ & $\begin{array}{l}\text { Journal Of Cleaner } \\
\text { Production }\end{array}$ & 2015 & 172 \\
\hline
\end{tabular}

Finally, Figure 7 shows the annual trend in publications. It should be noted that the search cut-off date was February 2020. Although there is no clear trend, there are years such as 2012, 2014, 2017, and 2018 with increased publications. The years 2017 and 2018 saw 32 papers published, which indicates a growing scientific interest in this topic.

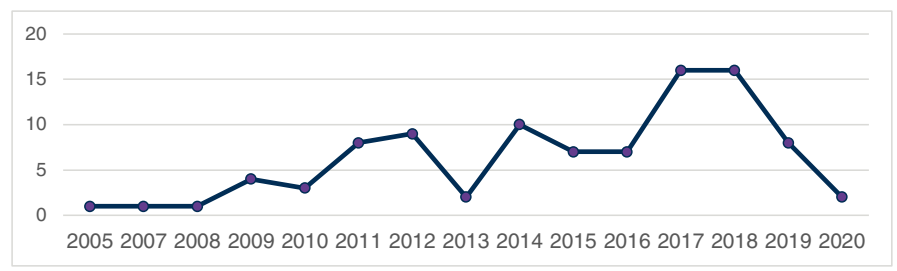

Figure 7

BP's Publications by year

Source: Authors' own elaboration.

\subsection{Results of the systemic analysis}

The work developed in this section focuses on review "lenses," as ProknowC proposes, centered around three key aspects. The first one focused on describing BP's theoretical bases, while the second lens was engaged in measuring and describing the variables worked with, and the last one sought to determine management and future research opportunities. This analysis and the lenses focused on analyzing the thirty most relevant documents in the portfolio because they are the most representative and have the best citation rates, accounting for $80 \%$ of the BP's citations.

\subsubsection{Conceptual And theoretical bases}

Figure 8 presents the most used theories and the existing ties among them. These studies' authors are observed to employ 
two or more theories for an integrated approach to analysis. For instance, EMA aspects are well worked out in top BP research, which is, in turn, directly linked to Management Accounting affairs from an approach of more controlled, measurement, and disclosure. There is also a strong relationship with institutional theory. Buiñding on the work of Bhimani (2006), LangfieldSmith (2006), and Luft \& Shields (2006), these are the most worked on environmental issues that, in turn, are associated with organizational processes and relate to financial and operational realities.
Notions that emerge from this type of study, such as Carbon Management, Carbon Accounting, Carbon Management Accounting, and Carbon Management Systems, stand out. Based on similar literature review research (Stechemesser and Guenther, 2012; Ascui 2014; Glienke and Guenther, 2016; Busch and Lewandowski, 2018), Table 3 presents the BP's works dealing with these matters and that make an approach to them (see Figure 8).

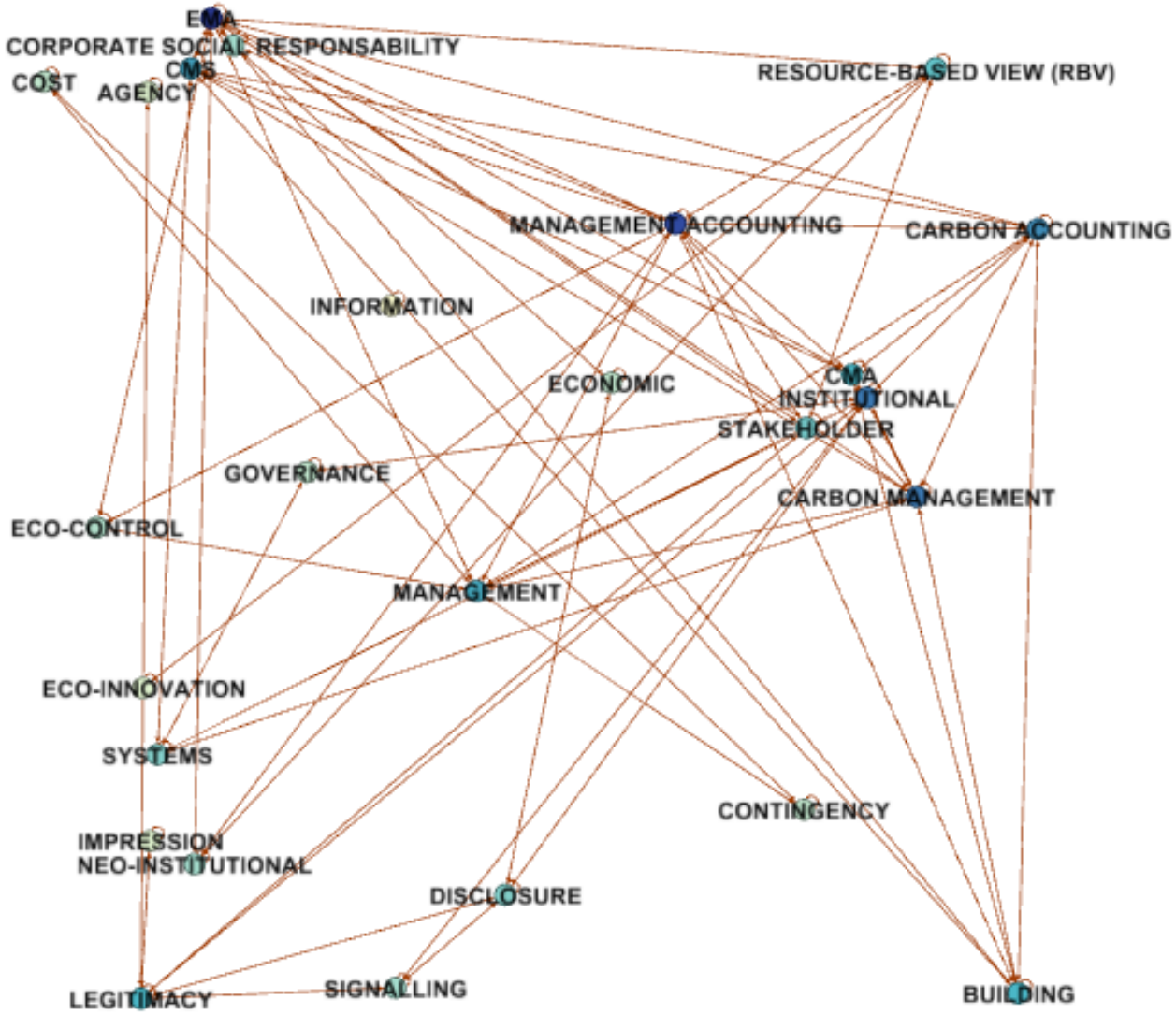

Figure 8

Theory Network

Source: Author's own elaboration using Gephi.

Table 3 presents the definitions of concepts emerging from these research papers, associated, in turn, with those shown in Figure 8. We also provide our own definition, which is a synthesis of the concept and is based on what each author asserts in their respective document. This summary of the key concepts is important both in the definition that we ventured to specify and in the similar concepts for two reasons: first, understanding what each concept refers to allows us to specify the research on the subject and to propose a cleaner idea of the research on the subject and its approach; this can also be key for organizations to report their information and their management. Second, establishing similar concepts also helps researchers to search for documents or articles related to the basic concepts. 
Table 3

Synthesis of Key Concepts

\begin{tabular}{|c|c|c|c|}
\hline Concept & Top BP & Definition & Similar concepts \\
\hline $\begin{array}{l}\text { Carbon } \\
\text { management } \\
(\mathrm{CM})\end{array}$ & $\begin{array}{l}\text { (Sullivan, 2009; Busch } \\
\text { and Hoffmann, 2011; } \\
\text { Lee, 2012; Acquaye et al., } \\
\text { 2014) }\end{array}$ & $\begin{array}{l}\text { Carbon management is closely related to decision-making matters } \\
\text { and involves a goal-setting stage and a policy focused on GHG } \\
\text { and carbon. Preparing and providing information on carbon } \\
\text { (accounting-based), supporting particular carbon-related decision- } \\
\text { making, directing and controlling strategies focused on emissions } \\
\text { management, and communicating carbon management strategies } \\
\text { internally and externally. }\end{array}$ & $\begin{array}{l}\text { Management of GHG } \\
\text { emission, emission } \\
\text { management, } \\
\text { Management of } \\
\text { Greenhouse Gas } \\
\text { Emissions, carbon } \\
\text { strategy. }\end{array}$ \\
\hline $\begin{array}{l}\text { Carbon } \\
\text { accounting (CA) }\end{array}$ & $\begin{array}{l}\text { (Gentil et al., 2009; } \\
\text { Lee, 2012; Schaltegger } \\
\text { and Csutora, 2012; } \\
\text { Stechemesser and } \\
\text { Guenther, 2012; } \\
\text { Acquaye et al., 2014; Lee } \\
\text { et al., 2015; Liesen et al., } \\
\text { 2015) }\end{array}$ & $\begin{array}{l}\text { There are two different approaches to carbon accounting, one related } \\
\text { to emission measurement and reduction, and another dealing with } \\
\text { financial implications: } \\
\text { 1. Activity related to measurement, carbon removal, and } \\
\text { maintaining a permanent inventory of operation-based emissions. } \\
\text { 2. Impacts on financial statements resulting from an entity's carbon } \\
\text { regulatory environment and emissions transaction strategies. }\end{array}$ & $\begin{array}{l}\text { GHG's Accounting, } \\
\text { Greenhouse gas } \\
\text { accounting, carbon } \\
\text { emission accounting, }\end{array}$ \\
\hline $\begin{array}{l}\text { Carbon } \\
\text { management } \\
\text { accounting } \\
\text { (CMA) }\end{array}$ & $\begin{array}{l}\text { (Ratnatunga and } \\
\text { Balachandran, 2009; } \\
\text { Burritt et al., 2011; Lee, } \\
\text { 2012; Schaltegger and } \\
\text { Csutora, 2012) }\end{array}$ & $\begin{array}{l}\text { Carbon Management Accounting (CMA) is a part of sustainability } \\
\text { accounting that provides information to make short- or long- } \\
\text { term decisions on carbon issues. CMA supports companies in } \\
\text { the successful operation and implementation of their carbon } \\
\text { management (CM) strategies. }\end{array}$ & $\begin{array}{l}\text { Carbon Business } \\
\text { Accounting, carbon } \\
\text { management control. }\end{array}$ \\
\hline $\begin{array}{l}\text { Carbon } \\
\text { management } \\
\text { system (CMS) }\end{array}$ & $\begin{array}{l}\text { (Burritt et al., 2011; } \\
\text { Schaltegger and Csutora, } \\
\text { 2012; Tang and Luo, } \\
\text { 2014; Corbett, 2018) }\end{array}$ & $\begin{array}{l}\text { Carbon Management Systems (CMS) refer to systems for } \\
\text { implementing carbon accounting management in organizations. } \\
\text { There are three particular purposes to it: responding to regulatory, } \\
\text { market, and social requirements, preparing sustainability reports in } \\
\text { accordance with the Global Reporting Initiative (GRI) and making } \\
\text { improvements in terms of sustainability for financial investment } \\
\text { analysis purposes. }\end{array}$ & \\
\hline
\end{tabular}

By the concepts in Table 3 and the documentary analysis, it can be stated at a general level that:

- Carbon accounting appears in response to the Kyoto Protocol to enable reporting on greenhouse gases. It also can be implemented mandatorily or voluntarily and at different scales (global, national, or corporate), thereby driving proactive environmental management.

- Three initiatives are dominant and set the guidelines for carbon reporting, to wit, the Greenhouse Gas Protocol (GHG), the Carbon Dissemination Project (CDP), and the Global Reporting Initiative (GRI).

- At the organizational level, carbon accounting refers to quantifying emissions based on the different scopes for preparing annual accounts and reports, thus enabling analysis, research, and consultation. The data that companies report on GHG emissions should include all three scopes-scope one deals with direct carbon emissions from sources owned or controlled by a company. Scope 2 is indirect carbon emissions associated with the procurement of electricity and steam consumed by the company. Scope 3 deals with other indirect emissions (not included in scope 2), including the supply chain up to entry into production, known as "from cradle to door" emissions.
- Carbon accounting procedures and tools for creating Scope-1 accounts are closely similar to financial and management accounting, Scope-2, and, in particular, Scope-3 limits require new approaches, challenging both accountants and sustainability managers. Therefore, companies begin to implement a variety of different carbon accounting methods and practices.

- Carbon management accounting requires the quantification of a company's direct and indirect emissions. Nevertheless, there is a lack of concepts and tools suitable for carbon performance measurement in production and supply chains.

- At the organizational level, carbon accounting can support carbon management and reduction measures for all corporate functions. It can also serve as a useful means to support companies in the successful start-up and implementation of their carbon management strategy.

- At the national level, carbon accounting can be summarized as physical measurement, and non-monetary valuation of GHG emissions caused not only directly and indirectly by humans in a nation or a smaller area, but also by natural disturbances, to understand the rate of emissions and develop and implement emission strategies, increase public interest, and influence international accounting standards. 
- Carbon emissions bring associated costs in the supply chain, which leads to economic impact in terms of the product price, profitability, or other factors to consider. In this regard, corporate carbon management can also be deemed a risk management activity capable of helping in preparing the company for a more carbon-constrained business environment in the future.

- Climate change adaptation and mitigation policies require technology development and deployment, which require financing and mainstreaming change at all levels. Governments should promote economic, financial, and budgetary incentives in their policies for companies to include within their strategies and organizational adequacy plans.

- Carbon accounting and carbon management accounting (CMA) can play a crucial role in providing carbon information in monetary and physical terms.

- Carbon management accounting can support decisionmaking at all organizational levels and better organize energy and material flows for substantial reduction purposes, regardless of whether a department is especially challenged to comply with regulations, or is motivated to increase ecoefficiency, product innovation, or legitimacy.

- CMA encompasses a set of information management tools that are used in carbon management and carbon policymaking in private and public organizations, which can support administrative decision-making roles and situations through specialized accounting tools.

- Managers have made efforts to develop and implement carbon management activities and to capture and disseminate related information.

- In their carbon and greenhouse gas management practices, large companies have set management responsibility and stipulated and published policies on climate or environmental change in their reports. They have also published their emissions inventories and set targets to reduce the intensity of their emissions.

- Another reason for participating in carbon management is the industry's pressure to provide information on its emissions and reduce such emissions as an act of environmental commitment. For some companies, it is the number of emissions trading certificates that can be avoided, resulting in direct savings. For other companies, the energy saved compensates the effort invested. However, other companies have tried to gain a market advantage by labeling their products as carbon neutral.

- Carbon management control can be developed and used for diagnostic and performance improvement purposes to improve sustainability, based on carbon accounting information.

-A sound CMS must be shaped around four perspectives: carbon governance, carbon operation, emissions monitoring, reporting, and commitment and disclosure. In turn, it should be in line with ISO 14001 standards for environmental management systems and current carbon practices.

\subsubsection{Methodologies of NOTE}

The research methods were classified based on the book Handbook of Management Accounting Research (Chapman et al., 2007). As shown in Figure 9, the most used method, found in $46 \%$ of these research papers, was the empirical methods, using both multiple and linear regressions to compare the hypothesis posed in these documents. Hence the importance of analyzing the most common variables and their impact on this research field.

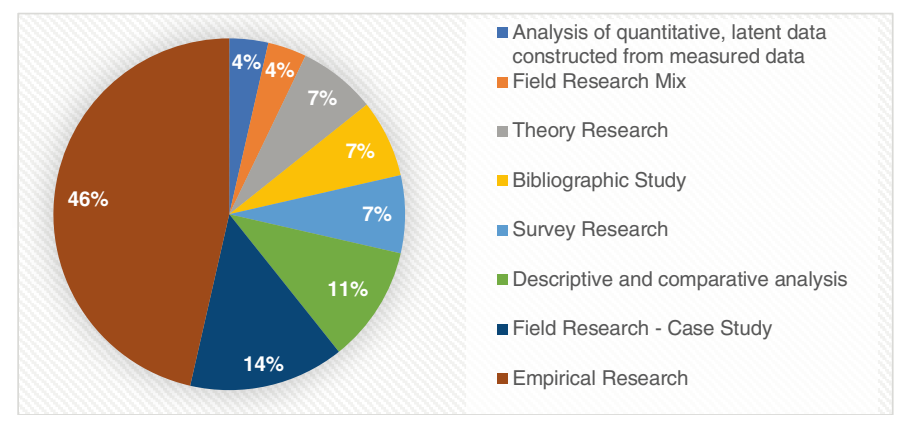

Figure 9

Research Method

Source: Authors' own elaboration.

Similarly, Figure 9 shows that there is a methodological combination with a qualitative approach, especially in those documents that focus on theoretical research or literature reviews, with $7 \%$ of the total $\mathrm{BP}$ analyzed. Likewise, it can be said that researchers have opted for research mechanisms such as case studies in $14 \%$ of cases, which shows that this methodology achieves an understanding of the business and management context and allows them to identify the changes that could occur. Although not widespread, the conclusions allow researchers to know the research opportunities in the field.

Also, note is the presence of qualitative articles complemented with quantitative data (11\%). By comparing, for example, accounting reports, these articles allow them to describe the corporate changes, differences and similarities with respect to the information they disclose on organizational management and, particularly, on carbon emissions or climate change within their business.

\subsubsection{VARIABLES USED}

The use of non-financial performance measures relates to alternative performance measures and means aligned with the organization's objectives (Ittner and Larcker, 2009). For Tang \& Luo (2014), carbon accounting research has addressed three critical issues: management's decision to voluntarily disclose carbon information, the impact of $\mathrm{CO} 2$ emissions and the climate change strategy on operational performance, and the value thereof for shareholders and environmental and carbon management.

Under this premise, and as measured above, the articles studied in the BP are empirical; therefore, we disaggregated the measures used by the authors for the econometric models, equations, and case studies, finding that these focus on three issues: finance and accounting, environmental measures, and those used as a control mechanism or the like.

As shown in Table 4, the measures that the authors most frequently used for the study of financial performance in relation to climate change are ROA, ROE, and Tobin's Q. These variables are related to the financial analysis ratios used to examine the business's status and decision-making, both internally and externally. Below are both the measures and the authors who use them, which serve as reference when creating the variables of an econometric model. 
Table 4

Financial Variables

\begin{tabular}{|c|c|c|}
\hline \multicolumn{3}{|r|}{ ACCOUNTING AND FINANCIAL } \\
\hline VARIABLE & MEASURE & AUTHOR \\
\hline ROA & Return on assets & $\begin{array}{l}\text { (Prado-Lorenzo et al., 2009; Busch and Hoffmann, 2011; Iwata and Okada, 2011; Rankin, } \\
\text { Windsor and Dina, 2011; Luo and Tang, 2014; Gallego-Álvarez et al., 2015; Lee et al., 2015; } \\
\text { Liesen et al., 2015) }\end{array}$ \\
\hline ROI & Return on investment & (Iwata and Okada, 2011) \\
\hline ROE & Return on equity & $\begin{array}{l}\text { (Wagner, 2005; Prado-Lorenzo et al., 2009; Busch and Hoffmann, 2011; Iwata and Okada, } \\
\text { 2011; Gallego-Álvarez et al., 2015) }\end{array}$ \\
\hline ROIC & Return on invested capital & (Iwata and Okada, 2011) \\
\hline ROS & Return on sales & (Wagner, 2005; Iwata and Okada, 2011) \\
\hline Q-TOBIN & Tobin's q & $\begin{array}{l}\text { (Wagner, 2005, 2010; Busch and Hoffmann, 2011; Iwata and Okada, 2011; Nishitani and } \\
\text { Kokubu, 2012; Wang et al., 2014; Lee and Min, 2015; Lee et al., 2015) }\end{array}$ \\
\hline МТВ & Market to Book ratio & (Prado-Lorenzo et al., 2009) \\
\hline ROCE & Return on capital employed & (Wagner, 2005) \\
\hline MKT & Market value of common equity & (Matsumura et al., 2014) \\
\hline MVE & Market value of equity & (Saka and Oshika, 2014) \\
\hline
\end{tabular}

It is evident that on top of financial information, non-financial information is necessary to study the different organizational contexts and be of interest to investors, the government, and the general public. It should be acknowledged that non-financial information is not as developed as financial accounting, but when the need for information arises, so do the tools, systems, and schemes to support it (Bebbington and Larrinaga-González, 2008). Table 5 summarizes the BP's non-financial variables, especially those related to greenhouse gases.
As shown in Table 5, one approach to the assessment of sustainable development performance is to implement and report on the actions related to sustainable development in the form of indicators (Bebbington, 2007). Several authors use this resource to develop their models and outline their research proposals. The construction of these indexes is based on previous data, previous studies, or experience.

Table 5

Environmental variables _ emission

\begin{tabular}{|c|c|c|}
\hline VARIABLE & MEASURE & AUTHOR \\
\hline Waste & Waste emissions (in the unit of tons) & (Iwata and Okada, 2011) \\
\hline Greenhouse gas & $\begin{array}{l}\text { Greenhouse gas emissions (in the unit of tons of } \mathrm{CO} 2 \\
\text { equivalents) }\end{array}$ & $\begin{array}{l}\text { (Busch and Hoffmann, 2011; Iwata and } \\
\text { Okada, 2011) }\end{array}$ \\
\hline Quality management system & A dummy variable taking the one if the firm has ISO 9001 & (Wagner, 2008) \\
\hline $\begin{array}{l}\text { Environmental and disclosure } \\
\text { indexes }\end{array}$ & Built by the authors. & $\begin{array}{l}\text { (Wagner, 2008; Prado-Lorenzo et al., 2009; } \\
\text { Nishitani, 2010; Matsumura et al., 2014) }\end{array}$ \\
\hline Iso 14001 & Variable related to ISO14001 certification & $\begin{array}{l}\text { (Nishitani, 2010; Nishitani and Kokubu, } \\
\text { 2012) }\end{array}$ \\
\hline Total output of CF & $\begin{array}{l}\text { Total carbon footprint is the total Raw material plus } \\
\text { Manufacturing plus Distribution }\end{array}$ & (Lee and Cheong, 2011) \\
\hline Cod & Emission of chemical oxygen demand per output $(\mathrm{kt} / \mathrm{t})$ & (Wagner, 2005) \\
\hline So2 & Emission of sulfur dioxide per unit of output $(\mathrm{kt} / \mathrm{t})$ & (Wagner, 2005) \\
\hline Nox & Emission of nitrogenous oxides per unit of output $(\mathrm{kt} / \mathrm{t})$ & (Wagner, 2005) \\
\hline Energy input & $\begin{array}{l}\text { Total energy input per unit of output }(\mathrm{GW} \mathrm{h} / \mathrm{t}) \\
\text { An indicator equal to } 1 \text { if a firm belongs to an energy-intensive } \\
\text { industry and } 0 \text { otherwise. }\end{array}$ & (Wagner, 2005; Lee et al., 2015) \\
\hline
\end{tabular}




\begin{tabular}{|c|c|c|}
\hline Water input & Total water input per unit of output $(1000 \mathrm{l} / \mathrm{t})$ & (Wagner, 2005) \\
\hline Vemd_disc & $\begin{array}{l}\text { One of the firms voluntarily discloses GHG emissions, and } 0 \\
\text { otherwise. }\end{array}$ & (Rankin et al., 2011; Liesen et al., 2015) \\
\hline EMS & $\begin{array}{l}\text { A vector of EMS category variables includes } n=3 \text { categories: } \\
\text { firms having no EMS, having a non- certified EMS, and having } \\
\text { an EMS that is ISO } 14001 \text { certified. }\end{array}$ & (Rankin et al., 2011) \\
\hline Env_com & Environment committee & $\begin{array}{l}\text { (Wagner, 2008; Rankin et al., 2011; Lee et al., } \\
\text { 2015) }\end{array}$ \\
\hline ETS & The firm participates in the EU ETS. & (Rankin et al., 2011; Liesen et al., 2015) \\
\hline $\mathrm{CDP}$ & Used CDP questionnaire & $\begin{array}{l}\text { (Busch and Hoffmann, 2011; Sullivan and } \\
\text { Gouldson, 2012; Luo and Tang, 2014; Wang, } \\
\text { Li and Gao, 2014) }\end{array}$ \\
\hline $\begin{array}{l}\text { The corporate sustainability } \\
\text { performance index }\end{array}$ & Built by the authors. & (Wagner, 2005) \\
\hline Varemiss & $\begin{array}{l}\text { Variable is represented by the variation (increase or decrease) } 2 \\
\text { in GHG emissions }\end{array}$ & $\begin{array}{l}\text { (Matsumura et al., 2014; Gallego-Álvarez } \\
\text { et al., 2015) }\end{array}$ \\
\hline $\mathrm{TCO} 2$ & Denotes carbon emissions total in thousands of metric tons & $\begin{array}{l}\text { (Matsumura et al., 2014; Wang et al., 2014; Lee } \\
\text { et al., 2015) }\end{array}$ \\
\hline Co2 productivity & Sales-emission Relationship & $\begin{array}{l}\text { (Nishitani and Kokubu, 2012; Saka and } \\
\text { Oshika, 2014; Lee and Min, 2015) }\end{array}$ \\
\hline Cdli & Carbon Disclosure Leaders Index (CDLI) & (Luo and Tang, 2014) \\
\hline En_tax & Energy tax-related. & (Liesen et al., 2015) \\
\hline
\end{tabular}

Another series of studies focuses on describing variables that organizations could study internally, and provide a working framework applicable mainly to the processing and study of carbon management accounting (CMA) and carbon management systems (CMS) (Acquaye et al., 2014; Burritt et al., 2011; Corbett, 2018; Gentil et al., 2009; Lee, 2012; Ratnatunga and Balachandran, 2009; Schaltegger and Csutora, 2012; Stechemesser and Guenther, 2012; Sullivan, 2009; Talbot and Boiral, 2018; Tang and Luo, 2014).

\subsubsection{RESEARCH OPPORTUNITIES ${ }^{4}$}

There are several poorly explored or unexplored key issues in carbon management accounting. So, accounting researchers are challenged to develop management control, differentiated accounting, and practical approaches that can be used effectively and efficiently to help companies reduce their carbon footprint, and improve the identification and allocation of corporate activities' carbon emissions to propose improvements in administrative control and management. (Ratnatunga and Balachandran, 2009; Schaltegger and Csutora, 2012).

\footnotetext{
${ }^{4}$ As shown in the section, this is the result of the analysis of each of the most representative $\mathrm{BP}$ documents and is summarized in these categories based on the experience of the authors and the methodological tool used in this research, i.e., ProknowC.
}

Our systemic analysis of the BP allowed determining vital points to be worked on from different perspectives, providing an account of the opportunities present at the political, management, research, and organizational levels.

Academic research. The studies analyzed reinforce three aspects of academic and research work related to carbon studies (Burritt et al., 2011; Corbett, 2018; Luo and Tang, 2014; Matsumura et al., 2014; Rankin et al., 2011; Saka and Oshika, 2014; Schaltegger and Csutora, 2012; Stechemesser and Guenther, 2012; Talbot and Boiral, 2018; Tang and Luo, 2014; Wagner, 2005, 2008).

1. Academic works should improve index construction and data collection to avoid subjectivity in model building and interpretation of results. To avoid this problem, research networks need to be strengthened, and interdisciplinary work be carried out in order to obtain primary-source data from different organizations, especially from bodies such as GRI or CDP. This could ensure that relationships associated with $\mathrm{CO} 2$ emissions or the general climate change context be analyzed through disclosure mechanisms, market value, corporate image, or forms of corporate and managerial legitimacy.

2. Another fundamental challenge facing academics is proposing legislation, based on previous research and the results thereof, for the treatment and establishment of carbon accounting and management systems' elements that support companies, stakeholders, and other interested parties. 
3. A final area to be worked on and reviewed is meeting the need of accounting students. They will perform in a business environment with increasing environmental restrictions, primarily market-related actions that increasingly control carbon in terms of accounting and audit and managerial tasks.

Management and organizational. Different papers indicate that organizations are setting objectives in their management practices and formulating strategies focused on carbon reduction revolving around three aspects (Acquaye et al., 2014; Burritt et al., 2011; Busch and Hoffmann, 2011; GallegoÁlvarez et al., 2015; Gentil et al., 2009; Lee, 2012; Lee and Cheong, 2011; Lee et al., 2015; Liesen et al., 2015; Matsumura et al., 2014; Nishitani, 2010; Nishitani and Kokubu, 2012; Prado-Lorenzo et al., 2009; Rankin et al., 2011; Ratnatunga and Balachandran, 2009; Stechemesser and Guenther, 2012; Sullivan, 2009; Sullivan and Gouldson, 2012; Wagner, 2005, 2010; Wang et al., 2014):

1. Businesses need to continue to improve their proactive management practices to address climate change and meet market demands by providing and disseminating betterquality reporting and addressing environmental issues. The input of carbon data into the supply chain stands out, as these are the most difficult to disclose given the complexity in accounting for carbon emissions and the flexibility of carbon standards.

2. Carbon management covers a broad spectrum of strategic issues ranging from general objectives to marketing, new product development, pricing, international business, promotion, supply chain management, finance, and risk management. These aspects should be reinforced and involved in the organization's day-to-day and materialize actions conducive to obtaining certifications like ISO 14001 or establishing an environmental committee to deal with carbon emissions.

3. The quality of reporting needs improving beyond mere regulatory compliance, since non-financial information, such as climate change information, is increasingly attracting various economic and social groups. It is essential to assess economic impacts to recognize, make visible, and materialize the efforts made.

Political and regulatory. Different countries' policymaking roles and the lack of homogeneity in the issuance of carbonrelated standards are a recurring feature in research papers. (Iwata and Okada, 2011; Matsumura et al., 2014; Ratnatunga and Balachandran, 2009; Sullivan, 2009; Tang and Luo, 2014; Wang et al., 2014) Basically, it is stated that the messages public policymakers sent out and the actions taken by companies are greatly disconnected, a situation that needs to be improved and strengthened for better and more information. As far as the legislative framework is concerned, issues such as carbon emissions trading, investment in technology to reduce $\mathrm{CO} 2$ emissions, the calculation of carbon compliance costs, or the effectiveness of carbon taxes, among other measures in the political agendas, need reviewing.

\section{CONCLUSIONS AND FUTURE RESEARCH}

This research aimed to identify the relationships between climate change, mainly carbon, and management through a bibliometric and systemic review of the literature, thanks to the use and adaptation of Proknow-C, which enabled the selection of a bibliographic portfolio (BP) made up of 95 academic papers published until April 2020 in the Web Of Science and Scopus databases.

The earliest works on the topic date back to 2005 and the number of published papers has gradually increased. This type of work demands further development, particularly in data collection for empirical studies.

Our bibliometric analysis established the keywords used. Despitebeing theleast used keywords, topics such as "environmental disclosure," "governance," "ISO 14001," and "control systems and incentives" entail an opportunity for future research and bet on works that develop them in a way so as to generate inputs to economic, managerial and accounting knowledge.

Researchers like Marcus Wagner and Stefan Schaltegger have become authorities on this topic because their work focuses on or relates to carbon management issues, carbon management accounting, or similar topics. Countries such as Australia and Germany have begun to collaborate in a way so as to make possible more robust works that will be useful in the future, especially concerning empirical or case studies.

Keywords or concepts such as Carbon Accounting (CA), Carbon Management (CM), Carbon Management Accounting (CMA), and Carbon Management System (CMS) emerged in our systemic analysis, which, despite lacking a unified definition, provide scope for conceptual and theoretical research and development in this line.

This analysis enabled the synthesizing of the most commonly used variables, financial and non-financial, showing that different emission indexes, especially carbon emission indexes, are becoming a recurring topic in environmental measures-related studies when working on topics related to climate change. This careful analysis has shown that the above-mentioned is still a topic that the literature has yet to explore in depth because there are difficulties in obtaining data, so it would be essential to press at the institutional level for this type of information to be provided.

Further work should be done on research, organizational and business matters, and governmental or legislative aspects. An effort should be made to develop studies that show and value the usefulness of carbon data and provide information on the management of $\mathrm{CO} 2$ emissions to shed light on businesses', governments' and organizational efforts, making this issue more structured and consolidated.

Taken to the level of management accounting, as expressed by Ahrens \& Chapman (2006), it is essential to highlight the possibilities of management control systems as actionable resources, emphasizing the activities that both countries and companies can carry out to manage their carbon emissions. Further works should allow organizations to align efforts with organizational objectives to respond efficiently to different stakeholders concerning environmental affairs.

There were several limitations to the development of work. Data collection occurs on a specific date and timeframe, wherefore new papers and works will not be part of this study. An investigation 
bias is acknowledged on account of our decision regarding the papers' alignment; that is, a limitation arises from the processes of deleting, filtering, and purging information. Furthermore, we are aware that some documents (which may be relevant) have been left out due to using databases such as WOS and Scopus and prioritizing the search of documents in "English." Likewise, only scientific papers are taken into account as per the methodology, thereby excluding other types of publications. Finally, because publications were identified using keywords, publications may not have been found that match our research approach, as their title or abstract did not contain the required keywords.

\section{ACKNOWLEDGMENTS}

This document was produced thanks to the fact that Yenny Naranjo Tuesta was a beneficiary of the "Colombia Científica Pasaporte a la Ciencia Program of ICETEX" in the foco - país of Society, which financed her doctoral studies. The authors would like to thank the anonymous reviewers for their comments, which have considerably improved this document.

\section{REFERENCES}

Acquaye, A., Genovese, A., Barrett J., and Koh L. (2014). Benchmarking carbon emissions performance in supply chains. Supply Chain Management, 19(3), 306-321. https://doi.org/10.1108/SCM-11-2013-0419

Ahrens, T. and Chapman, C. S. (2006). Theorizing Practice in Management Accounting Research. Handbooks of Management Accounting Research, 1, 99-112. doi: 10.1016/S1751-3243(06)01003-0.

Ascui, F. (2014). A review of carbon accounting in the social and environmental accounting literature: What can it contribute to the debate? Social and Environmental Accountability Journal, 34(1), 6-28. doi: 10.1080/0969160X.2013.870487.

Bebbington, J. (2007). Accounting for sustainable development performance. Available at: http://www.loc.gov/catdir/toc/fy0803/2007282695.html.

Bebbington, J. and Larrinaga-González, C. (2008). Carbon trading: Accounting and reporting issues. European Accounting Review, 17(4), 697-717. doi: 10.1080/09638180802489162.

Bhimani, A. (2006). Comparative Management Accounting Research: Past Forays and Emerging Frontiers. Handbooks of Management Accounting Research, 1, 343-363. doi: 10.1016/S1751-3243(06)01013-3.

Burritt, R. L., Schaltegger, S. and Zvezdov, D. (2011). Carbon Management Accounting: Explaining Practice in Leading German Companies. Australian Accounting Review, 21(1), 80-98. doi: 10.1111/j.1835-2561.2010.00121.x.

Busch, T. and Hoffmann, V. H. (2011). How hot is your bottom line? linking carbon and financial performance. Business and Society, 50(2), 233-265. doi: 10.1177/0007650311398780.

Busch, T. and Lewandowski, S. (2018). Corporate carbon and financial performance a meta-analysis. Journal of Industrial Ecology, 22(4), 745-759. doi: 10.1111/jiec. 12591.

Caiado, R.G.G., de Freitas Dias, R., Mattos, L.V., Quelhas, O.L.G., and Leal Filho, W. (2017). Towards sustainable development through the perspective of eco-efficiency - A systematic literature review. Journal of Cleaner Production, 165, 890-904. https://doi. org/10.1016/j.jclepro.2017.07.166

Chapman, C. S., Hopwood, A. G. and Shields, M. D. (eds) (2007). Handbook of Management Accounting Research. Elsevier Ltd.

Corbett, J. (2018). Designing and Using Carbon Management Systems to Promote Ecologically Responsible Behaviors. Journal of the Association for Information Systems, 14(7), 339-378. doi: $10.17705 / 1$ jais. 00338 .

Csutora, M. and Harangozo, G. (2017). Twenty years of carbon accounting and auditing - a review and outlook. Society and Economy, 39(4), 459-480. doi: 10.1556/204.2017.39.4.1.

Dutra, A. et al. (2015). The construction of knowledge from the scientific literature about the theme seaport performance evaluation, International Journal of Productivity and Performance Management, 64(2), 243-269. doi: 10.1108/IJPPM-01-2014-0015.

van Eck, N. J. and Waltman, L. (2010). Software survey: VOSviewer, a computer program for bibliometric mapping. Scientometrics, 84(2), 523-538. doi: 10.1007/s11192-009-0146-3.

van Eck, N. J. and Waltman, L. (2017). Citation-based clustering of publications using CitNetExplorer and VOSviewer. Scientometrics, 111(2), 1053-1070. doi: 10.1007/s11192-017-2300-7.

Ensslin, L., Ensslin, S. R. and Dutra, A. (2014). PROKNOW-C: Un proceso para generación de conocimiento e identificación de oportunidades de investigación científica.

Gallego-Álvarez, I., Segura, L. and Martínez-Ferrero, J. (2015). Carbon emission reduction: The impact on the financial and operational performance of international companies. Journal of Cleaner Production, 103, 149-159. doi: 10.1016/j.jclepro.2014.08.047.

Garrigos-Simon, F. J., Narangajavana-Kaosiri, Y. and Narangajavana, Y. (2019). Quality in tourism literature: A bibliometric review. Sustainability (Switzerland), 11(14), 1-22. doi: 10.3390/su11143859.

Gentil, E., Christensen, T. H. and Aoustin, E. (2009). Greenhouse gas accounting and waste management., Waste management \& research. The journal of the International Solid Wastes and Public Cleansing Association, ISWA, 27(8), 696-706. doi: 10.1177/0734242X09346702.

Glienke, N. and Guenther, E. (2016). Corporate climate change mitigation: a systematic review of the existing empirical evidence. Management Research Review, 39(1), 2-34. doi: 10.1108/MRR-10-2013-0243.

Harangozó, G., Széchy, A. and Zilahy, G. (2015). Corporate Sustainability Footprints -A Review of Current Practices, in Schaltegger, S. et al. (eds) Corporate Carbon and Climate Accounting. Cham. Springer International Publishing, 45-76. doi: 10.1007/978-3-319-27718-9_3.

Herrera-Franco, G. et al. (2021). Worldwide research on geoparks through bibliometric analysis, Sustainability (Switzerland), 13(3), 1-32. doi: 10.3390/su13031175.

Ittner, C. D. and Larcker, D. F. (2009). Extending the Boundaries: Nonfinancial Performance Measures. Handbooks of Management Accounting Research, 3, 1235-1251. doi: 10.1016/S1751-3243(07)03002-7.

Iwata, H. and Okada, K. (2011). How does environmental performance affect financial performance? Evidence from Japanese manufacturing firms. Ecological Economics, 70(9), 1691-1700. doi: 10.1016/j.ecolecon.2011.05.010.

Kumarasiri, J. and Jubb, C. (2016). Carbon emissions risks and management accounting: Australian evidence. Journal of Small Business and Enterprise Development, 29(2), 1-15. doi: 10.1108/02656710210415703.

Langfield-Smith, K. (2006). A Review of Quantitative Research in Management Control Systems and Strategy. Handbooks of Management Accounting Research, 2(2003), 753-783. doi: 10.1016/ S1751-3243(06)02012-8.

Lee, K. H. (2012). Carbon accounting for supply chain management in the automobile industry. Journal of Cleaner Production, 36, 83-93. doi: 10.1016/j.jclepro.2012.02.023.

Lee, K. H. and Cheong, I. M. (2011). Measuring a carbon footprint and environmental practice: The case of Hyundai Motors Co. (HMC). Industrial Management and Data Systems, 111(6), 961-978. doi: 10.1108/02635571111144991.

Lee, K. H. and Min, B. (2015). Green R\&D for eco-innovation and its impact on carbon emissions and firm performance. Journal of Cleaner Production, 108, 534-542. doi: 10.1016/j.jclepro.2015.05.114. 
Lee, K. H., Min, B. and Yook, K. H. (2015). The impacts of carbon (CO2) emissions and environmental research and development (R\&D) investment on firm performance. International Journal of Production Economics, 167, 1-11. doi: 10.1016/j.ijpe.2015.05.018.

Liesen, A., Hoepner, A.G., Patten, D.M., and Figge F. (2015). Does stakeholder pressure influence corporate GHG emissions reporting? Empirical evidence from Europe. Accounting, Auditing and Accountability Journal, 28(7), 1047-1074. doi: 10.1108/AAAJ12-2013-1547.

Lovell, H., Bebbington, J., Larrinaga, C., and Sales de Aguiar T.R. (2013). Putting carbon markets into practice: A case study of financial accounting in Europe. Environment and Planning C: Government and Policy, 31(4), 741-757. doi: 10.1068/c1275.

Luft, J. and Shields, M. D. (2006). Mapping Management Accounting: Graphics and Guidelines for Theory-Consistent Empirical Research. Handbooks of Management Accounting Research, 1(2003), 27-95. doi: 10.1016/S1751-3243(06)01002-9.

Luo, L. and Tang, Q. (2014). Does voluntary carbon disclosure reflect underlying carbon performance? Journal of Contemporary Accounting and Economics, 10(3), 191-205. doi: 10.1016/j.jcae.2014.08.003.

Matsumura, E. M., Prakash, R. and Vera-Muñoz, S. C. (2014). Firmvalue effects of carbon emissions and carbon disclosures. Accounting Review, 89(2), 695-724. doi: 10.2308/accr-50629.

Mendes, A., Lopez-Valeiras, E. and Lunkes, R. J. (2017). Pluralistic ignorance: Conceptual framework, antecedents and consequences. Intangible Capital, 13(4), 781-804. doi: 10.3926/ic.1063.

Nishitani, K. (2010). Demand for ISO 14001 adoption in the global supply chain: An empirical analysis focusing on environmentally conscious markets. Resource and Energy Economics, 32(3), 395-407. doi: 10.1016/j.reseneeco.2009.11.002.

Nishitani, K. and Kokubu, K. (2012). Why Does the Reduction of Greenhouse Gas Emissions Enhance Firm Value? The Case of Japanese Manufacturing Firms, Business Strategy and the Environment. Business Strategy and the Environment, 21(8), 517529. doi: 10.1002/bse.734.

Prado-Lorenzo, J.M., Rodríguez-Domínguez L., Gallego-Álvarez, I., and García-Sánchez, I.M. (2009). Factors influencing the disclosure of greenhouse gas emissions in companies world-wide. Management Decision, 47(7), 1133-1157. doi: 10.1108/00251740910978340.

Rankin, M., Windsor, C. and Dina, W. (2011). An investigation of voluntary corporate greenhouse gas emissions reporting in a market governance system. Australian evidence, Accounting, Auditing and Accountability Journal, 24(8), 1037-1070.

Ratnatunga, J. T. D. and Balachandran, K. R. (2009). Carbon Business Accounting: The Impact of Global Warming on the Cost and Management Accounting Profession. Journal of Accounting, Auditing \& Finance, 24(2), 333-355. doi: 10.1177/0148558X0902400208.

Saka, C. and Oshika, T. (2014). Disclosure effects, carbon emissions and corporate value, Sustainability Accounting, Management and Policy Journal, 5(1), 22-45. doi: 10.1108/SAMPJ-09-2012-0030.

Schaltegger, S., Zvezdov, D., Alvarez Etxeberria, I., et al. (2015). Corporate Carbon and Climate Accounting. Edited by S. Schaltegger et al. Springer International Publishing. doi: 10.1007/978-3-31927718-9.

Schaltegger, S., Zvezdov, D., Günther, E., et al. (2015). Corporate carbon and climate change accounting: application, developments and issues, in Corporate Carbon and Climate Accounting. Springer International Publishing, 1-25.

Schaltegger, S. and Csutora, M. (2012). Carbon accounting for sustainability and management. Status quo and challenges. Journal of Cleaner Production, 36, 1-16. doi: 10.1016/j.jclepro.2012.06.024.

Stechemesser, K. and Guenther, E. (2012). Carbon accounting: A systematic literature review. Journal of Cleaner Production, 36, 1738. doi: $10.1016 /$ j.jclepro.2012.02.021.

Sullivan, R. (2009). The management of greenhouse gas emissions in large European companies. Corporate Social Responsibility and Environmental Management, 16(6), 301-309. doi: 10.1002/csr.187.

Sullivan, R. and Gouldson, A. (2012). Does voluntary carbon reporting meet investors needs? Journal of Cleaner Production, 36 (January), 60-67. doi: 10.1016/j.jclepro.2012.02.020.

Talbot, D. and Boiral, O. (2018). GHG reporting and impression management: An assessment of sustainability reports from the energy secto. Journal of Business Ethics, 147(2), 367-383. doi: 10.1007/s10551-015-2979-4.

Tang, Q. and Luo, L. (2014). Carbon management systems and carbon mitigation. Australian Accounting Review, 24(1), 84-98. doi: 10.1111/auar.12010.

Viegas, C.V., Bond, A.J., Vaz, C.R., Borchardt, M., Medeiros Pereira, G., Selig, P.M., and Varvakis, G. (2016). Critical attributes of Sustainability in Higher Education: A categorisation from literature review. Journal of Cleaner Production, 126, 260-276. doi: 10.1016/j. jclepro.2016.02.106.

Wagner, M. (2005). How to reconcile environmental and economic performance to improve corporate sustainability: Corporate environmental strategies in the European paper industry. Journal of Environmental Management, 76(2), 105-118. doi: 10.1016/j. jenvman.2004.11.021.

Wagner, M. (2008). Empirical influence of environmental management on innovation: Evidence from Europe. Ecological Economics, 66(23), 392-402. doi: 10.1016/j.ecolecon.2007.10.001.

Wagner, M. (2010). The role of corporate sustainability performance for economic performance: A firm-level analysis of moderation effects. Ecological Economics, 69(7), 1553-1560. doi: 10.1016/j. ecolecon.2010.02.017.

Wang, L., Li, S. and Gao, S. (2014). Do greenhouse gas emissions affect financial performance? - An empirical examination of Australian public firms. Business Strategy and the Environment, 23(8), 505-519. doi: 10.1002/bse.1790.

WRI \& WBCSD (2015). Gren Gas Protocol. World Resources Institute; World Business Council for Sustainable Development. Available at: http://ghgprotocol.org/.

Zvezdov, D. and Schaltegger, S. (2016). Decision support through carbon management accounting-a framework-based literature review, in Corporate Carbon and Climate Accounting, 27-44. doi: 10.1007/978-3-319-27718-9_2. 